\title{
Can exercise prevent postmenopausal osteoporosis?
}

\author{
E. Ernst \\ Postgraduate Medical School, University of Exeter, Exeter, UK
}

Keywords: Osteoporosis, exercise, physical medicine, prevention

There has recently been increased interest in the prevention, treatment and rehabilitation of osteoporosis. Being predominantly a problem of the elderly, it is likely to grow out of proportion in the near future - in 1950 our planet housed 200000000 individuals aged over 65 years; in the year 2025 it will be inhabited by 1100000000 people of that age range ${ }^{1}$. The goal must therefore be effective prevention of osteoporosis; exercise is a possible option with certain clear advantages, such as low cost and freedom from negative side effects, but it is an option that is sometimes neglected ${ }^{2}$.

\section{Inactivity, peak bone mass}

Physical inactivity is one of the recognized risk factors for osteoporosis; the doubling of rates of hip fracture in the past 30 years is thought to be partly caused by the drastic decrease of habitual activity ${ }^{3}$. Experimental findings support the hypothesis. Disuse, immobilization, denervation paralysis or prolonged space flight are all associated with marked bone loss ${ }^{4-16}$. Most notably, bed rest leads to a rapid and severe demineralization with a reduction in bone mass of about $1 \%$ per week. Much evidence shows that exercise can prevent oesteoporosis and hip fractures. Physically active individuals have higher bone densities than do age-matched controls, as shown in cross-sectional studies ${ }^{20}$. Peak bone mass is usually attained around menopause, and is substantially higher in trained compared with untrained individuals $^{21-26}$. Similarly, prospective trials demonstrate that pre-menopausal women can train to reach a higher peak bone mass ${ }^{27}$. A recent study on a sizeable $(n=352)$ population of perimenopausal activity revealed a clear positive correlation between exercise and bone density ${ }^{28}$. Bone mineral content can be significantly increased by regular exercise in middle-aged ${ }^{29}$ and elderly women ${ }^{30}$. Among other possible benefits, exercise reverses postmenopausal bone loss and reduces the risk of injury from falling ${ }^{31}$. A meta-analysis of six trials showed that exercise reduces the incidence of hip fracture by about $50 \%{ }^{3}$.

\section{Intensity of exercise}

Prescribing exercise to individuals at risk is, therefore, appropriate and may allow a reduction in

Address for correspondence: E. Ernst, Postgraduate Medical School, University of Exeter, Barrack Road, Exeter EX2 5DW, UK

(C) 1994 Butterworth-Heinemann Ltd 0306-3674/94/010005-02 medication and thus avoidance of the side effects of drug treatments.

Mild exercise probably gives no protection. Walking 7 miles $(11 \mathrm{~km})$ per week ${ }^{32}$, daily extension exercises $^{33}$, or aerobics ${ }^{34,35}$ do not increase bone mineral content in a clinically relevant way. More intense training, however, does seem to work $^{36,37}$ running or playing ball games twice a week for $1 \mathrm{~h}$ results in an increase of $3.5 \%$ in bone mineral content after 8 months ${ }^{38}$. Vigorous exercise such as jogging, rowing and stair climbing is followed by a $5.2 \%$ increase in lumbar bone mineral content after 9 months ${ }^{37}$. If continued for 4 years, such an intensive programme will totally reverse the involutionary bone loss after menopause ${ }^{38}$.

\section{Forms of exercise}

Weight-bearing exercises appear to yield the most bone gain $3,29,33,39$. Load-bearing is one primary function of the skeleton, and bone can adapt to changes in functional load by increasing its density and resistance.

Pure (intensive) aerobic training may well have an effect ${ }^{39-41}$. but poor compliance is a problem of clinical exercise trials ${ }^{35}$ and can reduce the benefit. Weight-bearing and aerobic exercises, with emphasis on the playful element, are most likely to encourage compliance and produce a clinically beneficial effect $^{41}$. More studies are required to define the optimal programme more closely.

\section{Mechanisms}

The mechanisms by which exercise can induce a response are unclear. The response of the bone is clearly to the strain that is applied, and so local mechanisms may be postulated. Mechanical stress might generate an electric signal ${ }^{42}$ creating alkaline conditions locally, which in turn favour new bone generation ${ }^{43}$. An involvement of prostaglandins ${ }^{44}$ or effects on vitamin D metabolism ${ }^{45}$ might also play an important role.

\section{Therapy}

Preliminary studies suggest that regular exercise could be used as a treatment in patients whose bone mass is already reduced. One study showed that intense loading exercises for $50 \mathrm{~min}$ three times a week for 5 months were followed by a $3.8 \%$ increase in bone mineral content, which is clinically relevant compared with the $2 \%$ loss in control individuals over the same time $e^{46}$. Another trial demonstrated 
that low-impact aerobic exercise did not prevent the age-related bone loss ${ }^{35}$, but the compliance in this programme was very poor.

\section{Discussion}

Regular exercise has a place in the prevention and, possibly, in the treatment of postmenopausal osteoporosis. Further studies are needed to identify optimal exercise regimens and define more closely the mechanisms by which exercise operates.

There are many other beneficial effects of exercise $^{47}$, and we should advise our patients accordingly.

\section{References}

1 Kane WJ. Osteoporosis, osteomalacia, and Paget's disease. In: Frymoyer JW, ed. The Adult Spine. New York, USA: Raven, 1991: 648.

2 Smith R. Osteoporosis after 60. Br Med J 1990; 301: 452-3.

3 Law MR, Wald NJ, Meade TW. Strategies for prevention of osteoporosis and hip fractures. Br Med J 1991; 303: 453-9.

4 Albright F, Burnett $\mathrm{CH}$, Cope O, Parson W. Acute atrophy of bone (osteoporosis) simulating hyperparathyroidism. J Clin Endocrinol Metab 1941; 34: 711-6.

5 Whedon GD, Shen E. Metabolic studies in paralytic acute anterior poliomyelitis. II. Alterations in calcium phosphorus metabolism. J Clin Invest 1957; 36: 966-81.

6 Issekutz B, Blizzard JJ, Burkhead NC, Rodahl K. Effect of prolonged bed rest on urinary calcium output. J Appl Physiol 1966; 21: 1013-20.

7 Geiser M, Trueta J. Muscle action, bone rarefaction, bone formation. J Bone Joint Surg [Br] 1958; 40-B: 282-311.

8 Howard JW, Parson W, Bigman RS. Studies on patients convalescent from fracture. 3. The urinary excretion of calcium phosphorus. Bull Johns Hopkins Hosp 1945; 77: 291-313.

9 Deitrick JE, Whedon GD, Sherr E. Effects of immobilization upon various metabolic physiologic functions of normal men. Am J Med 1948; 47: 3-36.

10 Minaire P, Meunier PJ, Edouard C, Bernard J, Courpron P, Pournet J. Quantitative histological data on disuse osteoporosis. Comparison with biological data. Calcif Tissue Res 1974; 17: $57-63$.

11 Nilsson BE. Post-traumatic osteopenia. A quantitative study of the bone mineral mass of the femur following fracture of the tibia in man using americium-241 as a photon source. Acta Orthop Scand 1966; 91: 1-55.

12 Westlin NE. Loss of bone after Colles' fracture. Clin Orthop Rel Res 1974; 20: 194-9.

13 Mazess RB, Wheadon GD. Immobilization and bone. Calcif Tissue Int 1983; 35: 265-7.

14 Young DR, Niklowitz WJ, Brown RJ, Jee WSS. Immobilization-associated osteoporosis in primates. Bone 1986; 7: 109-17.

15 Whedon GD, Lutwak L, Reid J et al. Mineral nitrogen metabolic studies on Skylab orbital space flights. Trans Assoc Am Physicians 1974; 87: 95-110.

16 Smith MC, Rambout PC, Vogel JM, Whittle M. Bone mineral measurement in experiment M078 in biomedical records from Skylab. NASA Publication 1977; 183-90.

17 Rambaut PC, Coode AW. Skeletal changes during space flight. Lancet 1985; 2: 1050-2.

18 Mack PB, LaChance PA, Vose GP, Vogt FB. Bone demineralization of foot and hand of Gemini-Titan IV, V, VII astronauts during orbital flight. Am J Roentgenol 1967; 100: 503-11.

19 Vogel JM. Bone mineral changes in the Apollo astronauts. In: Mazess RB, ed. Proceedings of the International Conference on Bone Mineral Measurements. Bethesda, USA: U.S. DHEW, 1973; 352-61.

20 Dalen N, Olsson KE. Bone mineral content and physical activity. Acta Orthop Scand 1974; 45: 170-4.

21 Jones JJ, Priest JD, Hayes WC, Tichenar CC, Nagel DA.
Humeral hypertrophy in response to exercise. J Bone Joint Surg [Am] 1977; 59-A: 204-8.

22 Nilsson BE, Westlin NE. Bone density in athletes. Clin Orthop 1971; 77: 179-82.

23 Huddlestion AL, Rockwell D, Kulund DN, Harrison RB. Bone mass in lifetime tennis athletes. JAMA 1980; 244: 1107-9.

24 Aloia JF, Cohn SH, Babu T, Abesamis C, Kalice N, Ellis K. Skeletal mass body composition in marathon runners. Metabolism 1978; 27: 104-7.

25 Lane NE, Bloch DA, Jones HH, Marshall WH Jr, Wood PD, Fries JF. Long-distance running, bone density osteoarthritis. JAMA 1986; 255: 1147-51.

26 Montoye HJU, Smith EL, Ferdon DF, Hawley ET. Bone mineral in senior tennis players. Sci J Sports Sci 1980; 2: 26-32.

27 Gleeson PB, Broptas E, LeBlanc A, Schneider VS, Evans HJ. Effects of weight lifting on bone mineral density in premenopausal women. J Bone Miner Res 1990; 5: 153-8.

28 Zhang J, Feldblum PJ, Fortney JA. Moderate physical activity and bone density among perimenstrual women. Am J Public Health 1992; 82: 736-8.

29 Chow A, Harrison JE, Notarius C. Effect of two randomized exercise programs on mass of healthy postmenopausal women. $\mathrm{Br}$ Med J 1987; 295: 1441-4.

30 Smith E, Reddan W, Smith P. Physical activity and calcium modalities for bone mineral increase in aged women. Med Sci Sports Exerc 1981; 13: 60-4.

31 Fiataronc MA, Marks EC, Ryan ND, Meredith CN, Lipsitz LA, Evans WJ. High intensity strength training in nonagenarians: effects on skeletal muscle. JAMA 1990; 263: 3029-34.

32 Sandler R, Canley J, Hom D. The effects of walking on the cross-sectional dimensions of the radius in postmenopausal women. Calcif Tissue Int 1987; 41: 65-9.

33 Sinaki M, Wunker HW, Offord KT. Efficacy of non-loading exercises in prevention of vertebral bone loss in postmenopausal women: a controlled trial. Mayo Clinic Proc 1989; 64: 762-9.

34 White MK, Martin RB, Yeater RA, Butcher RL, Radin EL. The effects of exercise on the bones of postmenopausal women. Int Orthop 1984; 7: 209-14.

35 Prince RL, Smith M, Dick JM et al. Prevention of postmenopausal osteoporosis. A comparative study of exercise, calcium supplementation, and hormone-replacement therapy. $N \mathrm{Engl}$ J Med 1991; 325: 1189-95.

36 Aloia JF, Cohn SH, Ostuni JA, Canc R, Ellisk. Prevention of involuntary bone loss by exercise. Ann Intern Med 1978; 9: 356-8.

37 Ayalon J, Simkin A, Leichter J, Raifmann S. Dynamic bone loading exercises for postmenopausal women. Arch Phys Med Rehabil 1987; 68: 280-3.

38 Krolner B, Toft B, Nielsen SP, Tondevold E. Physical exercise as prophylaxis against involuntary vertebral bone loss: a controlled study. Clin Sci 1983; 64: 541-6.

39 Dalsky GP, Stocke KS, Ehsani AA. Weight bearing exercise and lumbar bone mineral content in postmenopausal women. Ann Intern Med 1988; 108: 824-8.

40 Smith EL, Gilligan C, McAdam M, Ensign CP, Smith PE. Defering bone loss by exercise intervention in premenopausal and post-menopausal women. Calcif Tissue Int 1989; 44: 312-21.

41 Preisinger E, Alacamlioglu Y, Schneider B, Bosina E, Heytmanek G, Metka M. Does regular exercise prevent bone loss? Eur J Phys Med Rehabil 1991; 1: 70-3.

42 Eriksson C. Streaming potentials and other water-dependent effects in mineralized tissues. Ann NY Acad Sci 1974; 238: 321-38.

43 Patt GH. The influence of $\mathrm{pH}$ on growth of bone in tissue culture. Proc Soc Exp Biol Med 1948; 68: 288-93.

44 Bindema I, Somejen D, Shimshan Z, Harell A. Role of prostaglandins in bone remodelling induced by physical forces. In: Menczel J, Robin GC, Makin M, Steinberg R, eds. Osteoporosis. Chichester, UK: John Wiley, 1982: 192-9.

45 Bell NH, Godsen RN, Henry DP, Shary J, Epstein S. The effects of muscle-building exercise on vitamin $D$ mineral metabolism. J Bone Miner Res 1988; 3: 369-73.

46 Simkin A, Ayalon J, Leichter J. Increased tubular bone density due to bone-loading exercises in postmenopausal women. Calcif Tissue Int 1987; 40: 59-63.

47 Ernst E. How exercise prolongs life. Eur J Phys Med Rehabil 1991; 1: 79-81. 